JANINA STANKIEWICZ

HANNA BORTNOWSKA

PATRYCJA ŁYCHMUS

\title{
Conditions necessary to maintain work-life balance of employees - in the light of the research results
}

Professor Janina Stankiewicz University of Zielona Góra

Ph. D. Hanna Bortnowska University of Zielona Góra

Ph. D. Patrycja Łychmus University of Zielona Góra

\section{Introduction}

One of the factors that may lower the efficiency of the organization members is a multiplication of their duties resulting from their occupational roles. This is due to growing expectations from employees and it could result in the appropriation of their private time by professional sphere. This issue is the subject of theorists' deliberations, who are involved in the functioning of the people in the company (Allen 2013; Borkowska 2010; Clutterbuck 2005; Gross-Golacka 2008; Riedmann 2006; Robak 2010; Visser, Williams 2006), as well as the subject of various studies on the very nature of social diagnoses. For example, according to the "Population time budget studies", conducted every 10 years 1 by the Central Statistical Office (GUS 2005), up to $40 \%$ of workers do not have time for themselves and focus solely on fulfilling nonwork responsibilities. Almost three-quarters $(64 \%)$ of respondents would undertake gainful

1 Latest study results in this field were published by the Central Statistical Office in 2005. The next edition ends in 2014. 
employment during the weekends. According to research carried out in 2009 by the Institute of Occupational Health in Helsinki, excessive working time can have a negative impact on cognitive functions of the employee. It may constitute a source of insomnia, ongoing stress and problems with concentration. In extreme cases, it can lead to chronic diseases of the nervous system, or even death (Dylagg 2009). These consequences prompt to reflect on the actions which foster a balance of employees, undertaken not only by themselves, but also their employers or the state.

The concept of work-life-balance is a part of a broader spectrum dealing with the human functioning in the areas important to them. According to D. Clutterbuck (2005, p. 26), it is a condition in which "the individual copes with potential conflict between different requirements regarding their time and energy in a way that their desire for prosperity and fulfillment is being met". The work-life balance, according to M. Sochanska and the research team (2013), is associated with the individual's ownership of autonomy in terms of when, where and how much time they spend on professional and private activities.

Although the term work-life balance may indicate that the person who wants to achieve it should "equally" divide her or his time between these spaces, it should be understood more broadly as "the effectiveness of the relationship between work and personal life" (cf. Riordan 2014). It also exists when one's work is harmonized with other aspects of one's life. Playing various roles by an individual, such as: parent, partner or employee, may improve the person's psychophysical condition - especially when all these roles are being played properly and are managed as a whole (Greenhaus, Powell, quoted in: Riordan 2014). In such case, private life can become an ally of working life, and vice versa. It is worth noting that the ideal condition is the one in which all the activities associated with performing multiple roles remain in line with the core personal values and serve as a means of achieving the goals of both professional and personal nature.

The purpose of this article is to answer the question of whether the working conditions provided by employers promote, in the opinion of their employees, maintaining a balance between work and non-work life. In order to do so, in April and May 2013, the research was conducted.

\section{Work-life balance in the context of managing the organization}

The Work-Life Balance (in short: WLB) can be analyzed at both the individual (employee's) and organizational level (cf. Borkowska 2010). At the individual 
level, WLB means the ability to combine work with other dimensions of life - family, health, social activity, private interests, etc. (Daniels, quoted in: Borkowska 2010, p. 8). It is important that a balance between work and nonwork life is an individual matter for each employee and it depends, among others, on socio-demographics (age, sex, health, education, inner motivation, family situation, upbringing, etc.), organization (specific elements of culture in the organization, management styles preferred by managers, implemented strategies regarding human resource management, company's condition, etc.), regional and national culture as well as national economic situation, especially the one existing in the labor market (Borkowska 2010). Employers wishing to take care of the WLB among employees should use institutional tools on the organizational level, hence creating such working conditions which take account of the needs of its members in terms of achieving and maintaining a balance between professional and private life. Therefore, as indicated by $\mathrm{L}$. Levi2 (2013), ones may:

- set the working hours so that the employees can avoid conflicts between their non-work needs and responsibilities,

- allow employees to participate in decision-making and actions affecting their workplace,

- check whether employees have enough time to complete their duties; allow them to rest after tasks requiring physical or mental effort,

- clearly define roles and professional responsibilities of employees,

- formulate duties to employees so that they give a sense of purpose, allow using their skills and contribute to their development,

- make sure the work atmosphere is free from any form of discrimination,

- avoid ambiguity in matters of job security and career development of employees, promote the acquisition of new skills.

L. Levi's concept and WLB factors which were listed by him became the basis of our own empirical research. During that research a direct survey technique was used. One of its objectives was to prepare a ranking of deficits in fulfillment of conditions of work-life balance of employees who took part in a survey.

2 L. Levi - Emeritus Professor of Psychosocial Medicine at the Karolinska Institutet in Stockholm, founder of the stress studies branch at the Swedish National Institute of Psychosocial and Health Factors, adviser for the World Health Organization and the European Commission.

Conditions necessary to maintain work-life balance of employees - in the light of the research results 


\section{Research methodology and characteristics of the research sample}

The research involved one hundred ninety six randomly-selected people workers employed in companies located in lubuskie Voivodeship. The sample size was established using an unreturnable sampling scheme (Szreder 2004, p. 121). The questionnaire which was used during the research consisted of fortytwo questions: closed (single choice) and open (twelve questions concerned the balance between professional and private life of employees). The following types of scales were used: alternative nominal, monopole ordinal, position and Likert. Eight socio-demographic variables characterizing the respondents were included in a questionnaire.

Among the respondents, the majority were women (62\%). The respondents differed in terms of: age [more than half $(60 \%)$ were aged 21-30 years, one in four (25\%) was aged 31-40 years, the thirteenth (about 8\%) - 41 - 50 years and a few (3.5\% each, $7 \%$ in total) were less than 21 or over 50 years old], position (80\% worked at an executive position, the other $20 \%$ at the managerial), work experience [nearly a quarter (24\%) had a total seniority ranging from 11 to 20 years, every third - of 1 to 3 years (29\%) or from 4 to 10 years $(29 \%)$, one in ten $(10 \%)$ - less than a year, and the thirteenth (approximately 8\%) - more than 20 years) and the length of the current employment [one third (33\%) worked in the current employment for 1 to 3 years, a quarter of respondents - no longer than a year $(26 \%)$ or from 4 to 10 years (24\%), one in seven (14\%) - from 11 to 20 years, and only a few (3\%) - more than 20 years].

The respondents worked in organizations of different sizes (small company - 32\%, large - 27\%, micro - 23\%, middle-sized - 18\%) and industry (15\% of respondents were employed in administration, $6 \%$ - in production companies, $9 \%$ - in production and service, $45 \%$ - in service, and $25 \%$ - in other branches, e.g. in trade). As can be seen from the analysis of this description of the research sample, the majority of respondents were less than 40 years $(85 \%)$, and worked for their current employment for not more than 10 years (83\%). The vast majority (70\%) was employed in service or trade companies.

\section{Deficits in work-life balance in opinions of employees of lubuskie Voivodeship}

The respondents indicated whether, in their case, at their current place of employment, the necessary conditions to maintain a balance between professional and private-life activities are met. The study focused on the negative 
responses which pointed to the deficits in particular areas. Drawn up was the ranking for these conditions - from the rarest to the most commonly existing at the workplace of the respondents. It is shown in figure 1.

The data presented in figure 1 shows that there are different gaps in the fulfillment of the conditions of the work-life balance. This begs the question:

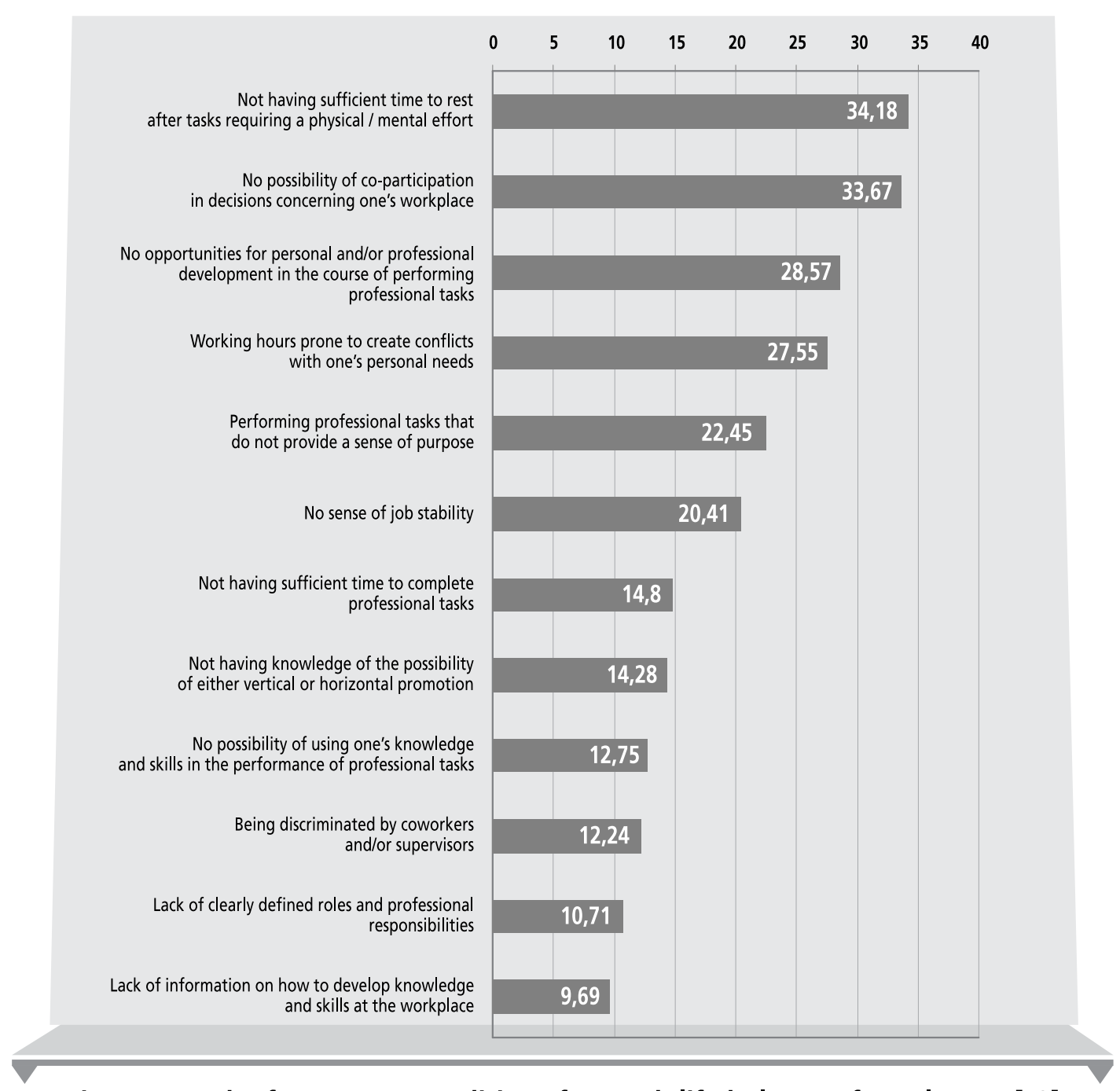

Figure 1. Lack of necessary conditions for work-life balance of employees [\%]

Source: own study based on the results of empirical research 
what relationships exist between these conditions and socio-demographic characteristics of the respondents? In order to answer this, Cramer's V ${ }^{3}$ coefficient values were verified (table 1 ).

Data found in table 1 indicates that the relationship between the researched WLB conditions and socio-demographic characteristics of respondents are weak (analyzed factor assumed values from 0.06 to 0.35 ). Therefore, further analysis focused solely on those relationships in which Cramer's V is higher than 0.20 .

Table 1. V-Cramer's values for the relationship between WLB conditions and characteristics of the respondents

\begin{tabular}{|c|c|c|c|c|c|c|c|c|}
\hline \multirow{2}{*}{$\begin{array}{c}\text { Con- } \\
\text { dition } \\
\text { num- } \\
\text { ber }\end{array}$} & \multicolumn{8}{|c|}{ Characteristics of respondents } \\
\hline & Age & $\begin{array}{l}\text { Gen- } \\
\text { der }\end{array}$ & $\begin{array}{l}\text { Seniority at } \\
\text { the current } \\
\text { place of em- } \\
\text { ployment }\end{array}$ & $\begin{array}{c}\text { Seniority } \\
\text { in total }\end{array}$ & $\begin{array}{c}\text { Type of } \\
\text { job }\end{array}$ & $\begin{array}{l}\text { Type of } \\
\text { contract } \\
\text { with the } \\
\text { employer }\end{array}$ & $\begin{array}{c}\text { Number of } \\
\text { employees } \\
\text { in the com- } \\
\text { pany }\end{array}$ & $\begin{array}{c}\text { Type } \\
\text { of } \\
\text { busi- } \\
\text { ness }\end{array}$ \\
\hline 1 & 0,15 & 0,28 & 0,24 & 0,15 & 0,18 & 0,12 & 0,15 & 0,19 \\
\hline 2 & 0,15 & 0,15 & 0,16 & 0,13 & 0,35 & 0,17 & 0,14 & 0,15 \\
\hline 3 & 0,17 & 0,11 & 0,16 & 0,19 & 0,29 & 0,18 & 0,16 & 0,17 \\
\hline 4 & 0,14 & 0,13 & 0,17 & 0,11 & 0,20 & 0,14 & 0,14 & 0,15 \\
\hline 5 & 0,12 & 0,06 & 0,12 & 0,12 & 0,19 & 0,19 & 0,17 & 0,13 \\
\hline 6 & 0,17 & 0,21 & 0,20 & 0,17 & 0,17 & 0,16 & 0,17 & 0,13 \\
\hline 7 & 0,14 & 0,16 & 0,17 & 0,15 & 0,09 & 0,13 & 0,17 & 0,18 \\
\hline 8 & 0,20 & 0,14 & 0,19 & 0,20 & 0,27 & 0,13 & 0,19 & 0,15 \\
\hline 9 & 0,22 & 0,14 & 0,15 & 0,20 & 0,20 & 0,22 & 0,18 & 0,17 \\
\hline 10 & 0,13 & 0,10 & 0,22 & 0,15 & 0,03 & 0,16 & 0,14 & 0,16 \\
\hline
\end{tabular}

3 Cramer's $\mathrm{V}$ coefficient takes values from 0 to 1 . The article includes the following scale correlation: $|\mathrm{r}|=0$ (no correlation exists), $0<|\mathrm{y}|<0.3$ (poor), $0.3 \leq|\mathrm{y}|<0.5$ (average), $0.5 \leq|\mathrm{y}|<0.7$ substantial), $0.7 \leq|\mathrm{y}|<0.9$ (high), $0.9 \leq|\mathrm{y}|<1.0$ (very high), $|\mathrm{r}|=1$ (full, functional). This scale, however, tends to be contractual and sometimes recognized differently by the authors of statistical studies (Stanisz 2006). 


\begin{tabular}{c|c|c|c|c|c|c|c|c}
$\mathbf{1 1}$ & 0,14 & 0,07 & 0,12 & 0,16 & 0,12 & 0,12 & 0,11 & 0,14 \\
\hline $\mathbf{1 2}$ & 0,18 & 0,12 & 0,17 & 0,20 & 0,18 & $\mathbf{0 , 2 3}$ & 0,16 & 0,16 \\
\hline
\end{tabular}

\section{Explanation:}

1 - Not having sufficient time to rest after tasks requiring a physical / mental effort

2 - No possibility of co-participation in decisions concerning one's workplace

3 - No opportunities for personal and/or professional development in the course of performing professional tasks

4 - Working hours prone to create conflicts with one's personal needs

5 - Performing professional tasks that do not provide a sense of purpose

6 - No sense of job stability

7 - Not having sufficient time to complete professional tasks

8 - Not having knowledge of the possibility of either vertical or horizontal promotion

9 - No possibility of using one's knowledge and skills in the performance of professional tasks

10 - Being discriminated by coworkers and/or supervisors

11 - Lack of clearly defined roles and professional responsibilities

12 - Lack of information on how to develop knowledge and skills at the workplace

In the case of the first and most common (34.2\%) condition of imbalance - i.e. the respondents not disposing of sufficient time to rest after a task requiring a physical and/or mental effort - the strongest associations were found with regard to gender $(0.28)$ and seniority at the current place of employment (0.24). It was found that twice as many women (42\%:21\%) felt a deficit in this area. This may be connected with the women's moving away from the traditional model of performance of social and occupational roles in which they would undertake professional activities only if the husband's salary did not satisfy the needs of their family. Currently, individual decisions of women to take jobs are affected by several additional conditions, resulting from broader socio-economic as well as cultural and philosophical processes, including, among others, a "postponement syndrome" with regard to a decision of starting a family, the growing popularity

Conditions necessary to maintain work-life balance of employees - in the light of the research results 
of informal relationships, single motherhood, the concept of gender and, finally, the rise in unemployment. Increasingly, women's professional work is seen as an important source of income compared to that of men's (although women still earn less than men ${ }^{4}$ ). At the same time, in spite of the growing popularity of the partnership model, based on egalitarianism in terms of responsibilities, it remains a model that is desired (expected) by women and only declaratively supported by men, who positively relate to it as a pattern, and not as much as a basis for the functioning of their own family (Balcerzak-Paradowska 2008, p. 12). This has been confirmed by the results of research carried out by A. Titkow , D. Duch-Krzystoszek and B. Budrowska (2004) . The research revealed that women, as compared to men, spend over forty hours a week more committing to work in the "private sphere " (including ten hours of domestic chores, almost thirty hours of childcare up to 10 years old, and about five and a half hour to take care for dependents and the elderly). As a result, women work in the household the whole dimension of time more than men. Analyzing the second metric variable, important from the perspective of the researched WLB condition - i.e. seniority at the current place of employment - it was found that the longer it was, the more the respondents lacked time to rest after strenuous tasks (those working less than a year $-21.2 \%$, from 1 to 3 years $-32.3 \%$, from 4 to 10 years $-40.4 \%$, from 11 to 20 years $-44.4 \%$, more than 20 years $-100 \%$ ). The explanation may have to do with an "overload" of professional duties of the more experienced members of the organization, who can be entrusted with more difficult and responsible tasks. One needs to devote much more time to complete such tasks; they are also more engaging, both emotionally and physically. Furthermore, as has been pointed out by M. Szymańska and K. Wolski (2013), experienced employees are promoted more often and, although this usually triggers a sense of pride and reinforces their positive self-esteem, new responsibilities and a broader range of competencies come with greater amount of stress and less amount of time to rest.

An analysis of respondents' statements regarding another WLB condition - i.e. the possibility of co-participation in decisions affecting one's workplace - showed that one third of employees $(33.67 \%)$ do not have a chance to do so. The highest value of Cramer's V coefficient was obtained with respect to the following variable: type of position held in the company - 0.35. Employees, in

4 Average total gross salary for men in 2012 amounted to 4500 PLN, while women - only 3500 PLN (GUS 2012). 
comparison with managers, were twice as likely (37.3\%: 18.4\%) to emphasize the lack of influence on decisions concerning their work. It is possible that the surveyed managers more often participated in decision-making and matters relating to the functioning of the company as compared to their subordinates. It is because - and it has been confirmed by research of P. Bernstein (quoted in: Stankiewicz, Moczulska 2007) - the lower the level in the organizational hierarchy, the lower the impact of employees on making decisions in their workplace. Another explanation of such relationship may be found in research indicating that employees tend to be unaware of participating in decisionmaking (for example, when the manager applies a consultative management style, while not explaining the reasons for consulting his or her subordinates) (Stankiewicz, Moczulska 2009). It is certainly not conducive to maintaining a balance between work and private life of employees.

Type of position held in the company is a variable, in which case, again, one of the highest Cramer's V coefficient value (0.29) was obtained with respect to another important WLB condition - opportunities for personal and/or professional development in the course of professional tasks. Deficits in this area were indicated by more than a quarter of the respondents $(28.57 \%)$, including $23.7 \%$ of managers and $29.8 \%$ of "performers". Given that the ongoing personal and/or professional development can increase the value of the employee in the eyes of the employer, and thus have a positive effect on their stable position in the company, being aware of the limited opportunities in this field can substantially reduce the sense of balance between work and private life. What is more, employees believe that permanent self-improvement is an asset in today's job market, which tends to be more and more demanding, and the chances of employment are reserved for those who are geared to the development of their own skills and competences (cf. Stankiewicz, Bortnowska 2011; Stankiewicz, Bortnowska, Łychmus 2009). The indicated feature of the modern labor market may exacerbate the lack of sense of balance of the respondents, considering that over the fifth of them $(20.41 \%)$ did not feel the stability of employment. Cramer's $\mathrm{V}$ coefficient, in relation to socio-demographic characteristics of the respondents, showed the highest values in the case of equality (0.21). Experiencing lack of employment turned out to be more true for women rather than men $(26.5 \%$ : $10.7 \%)$. It is worth noting that the research conducted by A. Titkow, D. DuchKrzystoszek and B. Budrowska in 2004 indicated that women tend to be more burdened by domestic chores. Consequently, they may be less flexible, have fewer opportunities to engage in improving their professional skills and competences and adapting them to the needs of the constantly growing business. This can

Conditions necessary to maintain work-life balance of employees - in the light of the research results 
significantly reduce their chances of employment on both internal and external labor market. Awareness of this may increase the sense of stability of employment among women, especially that the unemployment rate in Poland among women is higher than among men (GUS 2012).

A sense of job stability can also be reduced due to the lack of knowledge about one's professional future in the company, including potential horizontal and vertical promotions. Every seventh respondent (14.28\%) was not aware of the possibilities of career development at their current place of employment, which could have a negative impact on the WLB. An analysis of the respondents' statements showed a weak relationship between the lack of compliance of this WLB condition. Cramer's V coefficient for surveying socio-demographic characteristics of the respondents took the highest value (0.27) for the following variable: type of position held in the company. Only a small part of managers $(1.3 \%)$ and slightly more "performers" $(8.5 \%)$ did not have knowledge of this scope. The explanation for such state of matters may be determined by limited knowledge among "performers" about the company's strategic plans and, associated with them, personnel changes. It is possible that it might have intensified fears of employees for their own professional future in the company.

The observed deficit among respondents in terms the next WLB condition i.e. sense of incomplete usage of personal and professional potential - was most common among people under 21 (21.4\%) (Cramer's V coefficient has value of 0 , 22). Such persons, by virtue of a small professional experience, are usually entrusted with routine tasks, involving less responsibility, being less demanding and rarely giving them a chance to "prove themselves" at work. It should be added that this deficit could also be associated with the type of employment contract (Cramer's V coefficient was 0.22).

An important factor contributing to a sense of balance among working professionals is the belief of equal treatment by other members of the organization. Meanwhile, studies show that as many as one in eight respondents (12.24\%) claim to have had to deal with discrimination from colleagues and/ or supervisor. The highest Cramer's V coefficient value was obtained for the following variable: seniority at the current place of employment (0.22). Analyses indicate that discrimination is experienced more often, in opinions of the discriminated, against people working in the company for more than 4 years and less than 20 years - this was the response of almost one in ten of the respondents $(9.6 \%)$ with seniority from 4 to 10 years and a similar fraction $(9.3 \%)$ of those working from 11 to 20 years. Seniority in the organization has an impact on selfesteem, way of thinking and acting, as well as identifying through it with the 
goals of the organization (cf: Walczak 2011). People working in the company for several years are already familiar with the company's standards and customs, therefore it is easier for them to recognize situations that deviate from the norm (and such is, for instance, discriminatory behavior). People with a relatively short seniority (under 4 years), who are only getting to know the company's rules of conduct, may not be aware of the acts of discrimination, while people with a seniority of more than 20 years might have got used to them and not consider them reprehensible anymore (employees who did not agree with the situations of unequal treatment of other members of the company are probably no longer part of such organization).

A factor reducing a sense of balance between work and private life is unawareness of how to develop the knowledge and skills for the particular job position. As many as one in ten respondents $(9.69 \%)$ confirmed that he had no such knowledge. Cramer's coefficient attains the highest value $(0.23)$ in the case of the following variable: type of contract with the employer. Most of the respondents who did not know how to improve their present job position were those who have been employed on contract work or commission contract (10.3\%). This result is confirmed by research conducted by M. Sochańska and the research team $(2013, \mathrm{p}$. 160). It shows that such forms of employment are seen as "inferior" or are associated with "greater burden" than the classic "posts". This can have a negative impact on personal and professional life of the employees. In the opinion of many respondents, this kind of contracts act against their interests, limit the opportunities for professional development and promotion, and are associated with lower social security.

\section{Final remarks}

The reported deficits in the WLB of employees tend to reflect on the necessity to take corrective measures. They should be used in different areas of human functioning in society - both at the state as well as the organizational and individual level. An example of the state impact on the discussed realm is the implementation of activities in the field of family policy (e.g. granting birth grants, maternity benefits, preschool subsidies, tax credit for raising children, subsidies for textbooks, extension of maternity leave, co-financing of children under the age of 3 , etc.). Complemented by actions of the state in this regard would be the introduction of an organizational policy of "familyfriendly employment" (Sochańska et al. 2013) with the aim of balancing work and family life of employees. Among the many different ventures

Conditions necessary to maintain work-life balance of employees - in the light of the research results 
(usually referred to as Work-Life Programmes) undertaken as part of this policy, we should point out the possibility of using the following: flexible work arrangements (e.g. flexible working time, sabbaticals, telecommuting or compressed working time), assistance in the care of children (e.g. creating company crèches) and elderly family members, organizing information and training projects and consultancy (relating to coping with stress and professional burnout), co-financing of medical services and sports and recreational activities, as well as providing services related to domestic chores, such as organization of board, etc.

The implementation of these and other programmes is important since it creates opportunities to reduce such negative phenomena as professional deformation of personality (characterized by: excessive identification with the professional role, selective perception, impoverishment of interests, barrenness of thought, loss of the ability to correctly assess oneself and the surrounding world, a way of communication demonstrating separateness and distance to other people - cf: Mesjasz 2013), stress and professional burnout, family disputes, apathy, addiction or psychosomatic illnesses, which can lead to increased absenteeism, decrease in labor productivity and a greater prevalence of destructive conflict in the workplace. Such programmes can help employers in: reducing the fluctuation and absenteeism of personnel (and thereby reduce the cost of recruiting and training new employees), increasing loyalty and commitment of employees, improving the company's image as an employer, reducing the number of stress and conflict factors (and thereby improve overall comfort in the company). It can be therefore assumed that the efforts to maintain a balance between work and private life of employees have long-term preventive and protective character - for both employee and employer - and they work against a decline in the competitiveness of companies and the reduction of the employee's value on the labor market (cf. Sochańska et al. 2013).

\section{Summary}

\section{Conditions necessary to maintain work-life balance of employees - in the light of the research results}

The article presents the results of research concerning worklife balance of employees of enterprises located in lubuskie voivodeship. The working conditions provided by employers were analyzed. The authors of research checked whether they favor, according to the respondents, the homeostasis between work and 
private life. The results showed some deficits in this area. This led to reflection on the potential remedial actions which can be applied in the organization, such as a policy of "family friendly employment".

\section{Streszczenie}

Warunki zachowania równowagi między pracą zawodową a życiem prywatnym pracowników - w świetle wyników badań W artykule zaprezentowano wyniki badań dotyczących równowagi między pracą zawodową a życiem prywatnym pracowników lubuskich przedsiębiorstw. Szczegółowej analizie poddano warunki pracy zapewnione przez pracodawców. Sprawdzono, czy sprzyjają one, w ocenie respondentów, zachowaniu homeostazy między pracą a życiem pozazawodowym. Uzyskane rezultaty badań ujawniły pewne deficyty $\mathrm{w}$ tym zakresie. Skłoniło to do refleksji nad potencjalnymi środkami zaradczymi, np. wprowadzeniem w organizacji polityki „,zatrudniania przyjaznego rodzinie”.

\section{References}

1. Allen D. (2013), Życie i praca. Jak znaleźć czas na wszystko, Wyd. GWP, Gdańsk.

2. Balcerzak-Paradowska B. (2008), Polityka rodzinna w Polsce w aspekcie godzenia życia zawodowego i rodzinnego, in: C. Sadowska-Snarska, T. Li (eds.), Godzenie pracy z rodzina w kontekście aktywizacji zawodowej kobiet, Wyd. WSE w Białymstoku, Białystok.

3. Borkowska S. (2010), Równowaga między praca a życiem pozazawodowym, Acta Universitatis Lodziensis, Folia Oeconomica, Nr 240, Łódź.

4. Clutterbuck D. (2005), Równowaga między życiem zawodowym a osobistym, Oficyna Ekonomiczna, Kraków.

5. Dyląg B. (2009), RYNEK: Praca w nadgodzinach jest nieproduktywna, http:/ / www.hotmoney.pl/RYNEK-Praca-wnbspnadgodzinach-jestnieproduktywna-a9573, 25.11.2013 - data dostępu).

6. Greenhaus H.J., Collins M.K., Shaw D.J. (2003), The relation between workfamily balance and quality of life, "Journal of Vocational Behaviour", Vol. 63, pp. 510-531.

7. Gross-Gołacka E. (2008), Równowaga praca-życie jako element strategii zarządzania zasobami ludzkimi, w: C. Sadowska-Snarska (red.), Równowaga: praca - życie - rodzina, Wyd. Wyższej Szkoły Ekonomicznej, Białystok.

8. GUS (2005), Budżet czasu ludności, 1 VI 2003 - 31 V 2004, Główny Urząd Statystyczny, Warszawa.

Conditions necessary to maintain work-life balance of employees - in the light of the research results 
9. GUS (2012), Kobiety i mężczyźni na rynku pracy, Główny Urząd Statystyczny, Warszawa.

10. Kowalówka M. (2013), Nowa klasa prekariatu, http://rynekpracy.pl/ artykul.php/wpis.742 (20.01.2014 - data dostępu).

11. Levi L. (2013), Czy zaharowujemy się na śmierć? "Gazeta Wyborcza”, 23-24 marca; Are We Working Ourselves to Death?, http:/ / www.project-syndicate. org/commentary/are-we-working-ourselves-to-death- (09.01.2014 - data dostępu).

12. Mesjasz J. (2013), Zawodowa deformacja osobowości, http://www. miesiecznik-benefit.pl/index.php?wiad=483 (16.12.2013 - data dostępu).

13. OECD Employment Outlook 2013, http://www.oecd-ilibrary.org/ employment/oecd-employment-outlook-2013_empl_outlook-2013-en (25.11.2013 r. - data dostępu).

14. Riedmann A. (2006), Working time and work-life balance in European companies. Establishment Survey on Working Time 2004-2005, European Foundation for the Improvement of Living and Working Conditions, Dublin.

15. Riordan Ch. (2014), Work-life balance - tu nie chodzi o równowage, http:// www.hbrp.pl/news.php?id=1083\&t=worklife-balance-tu-nie-chodzi-orownowage, (25.11.2013 - data dostępu).

16. Robak E. (2010), Kształtowanie równowagi między praca a życiem osobistym pracowników jako istotny cel wspótczesnego zarządzania zasobami ludzkimi, in: D. Lewicka, L. Zbiegień-Maciąg (eds.), Wyzwania dla wspótczesnych organizacji w warunkach konkurencyjnej gospodarki, Wyd. AGH, Kraków.

17. Sadowska-Snarska C., Li T. (eds.) (2008), Godzenie pracy z rodziną w kontekście aktywizacji zawodowej kobiet, Wyd. WSE w Białymstoku, Białystok.

18. Sochańska M., Morysińska A., Makowska - Belta E., Kołakowska Seroczyńska Z., Szarfenberg R., Mering T. (2013), Elastyczne formy zatrudnienia - skutki społeczne i ekonomiczne, Wrocław, https://careers. uni.wroc.pl/media/uploads/Elastyczne_formy_zatrudnienia_skutki_ spoleczne_i_ekonomicznne.pdf (15.01.2014 - data dostępu).

19. Stanisz A. (2006), Przystępny kurs statystyki z zastosowaniem STATISTICA PL na przyktadach z medycyny, Tom 1. Statystyki podstawowe, StatSoft Polska Sp. z o.o., Kraków.

20. Stankiewicz J., Bortnowska H. (2011), Samodoskonalenie szansa na poprawe konkurencyjności pracowników na bankowym rynku pracy (w świetle wyników badań), „Przedsiębiorczość i Zarządzanie”, T. 12, z. 3.

21. Stankiewicz J., Bortnowska H., Łychmus P. (2009), E-coaching jako technika wspierająca rozwój zawodowy pracowników bankowych w trudnych czasach, in: S. Partycki (ed.), E-gospodarka, e-społeczeństwo w Europie Środkowej $i$ Wschodniej, Wyd. Katolickiego Uniwersytetu Lubelskiego, Lublin. 
22. Stankiewicz J., Moczulska M. (2007), Wspótudziat pracowników w podejmowaniu decyzji a sukces organizacji, Prace i Materiały Wydziału Zarządzania Uniwersytetu Gdańskiego, nr 1, Sopot.

23. Stankiewicz J., Moczulska M. (2009), Determinants of employee participation in management on the basis of the research results, "Management", Vol. 13, No. 2.

24. Szreder M. (2004), Metody i techniki sondażowych badań opinii, PWE, Warszawa.

25. Szymańska M., Wolski K. (2013), Młodzi kontra doświadczeni pracownicy komu najbardziej zagraża stres w pracy? http:/ / rynekpracy.pl/artykul.php/ typ.1/kategoria_glowna.26/wpis.670 (09.01.2013 - data dostępu).

26. Titkow A., Duch-Krzystoszek D., Budrowska B. (2004), Nieodpłatna praca kobiet. Mity, realia, perspektywy, Wyd. IFiS PAN, Warszawa.

27. Walczak W. (2011), Zarządzanie różnorodnościa jako podstawa budowania potencjału kapitału ludzkiego organizacji, „E-mentor", nr 3.

28. Visser F., Williams L. (2006), Work-life Balance: Rhetoric versus reality? The Work Foundation, London. 